\title{
Efficiency of Certain Natural Extracts and Antibiotics in Managing the American Foulbrood (AFB) of Honey Bees in Egypt \\ Mesbah, H.A., ${ }^{1}$ N.A.EL-Sayed ${ }^{1}$, M. E. Morsy ${ }^{2}$, M.B.EL-Kady, ${ }^{1}$ S.I. Behiry ${ }^{1}$ and G.A.EL-Hamamy ${ }^{1}$
}

\begin{abstract}
The Present study was initiated for controlling the American foulbrood (AFB) disease of honey bee colonies in six selected apiaries at El-Beheira and two apiaries at Kafr El- Sheikh Governorates. The performed control techniques were run along May 2016, upon inspected honey bee colonies of Carniolan hybrid, which were choosed to study and evaluate the efficiency of different used materials for the management of the American foulbrood (AFB) disease. These tested materials implied the antibiotics: Tylosin ${ }^{\circledR}$, Terramycin ${ }^{\circledR}$ and Sulfa dimidin sodium $^{\circledR} \mathbf{2 0} \%$. The following natural materials: Cinnamon oil, Propolis, Ginger, Aloe vera and Aprogin (Aloe vera+ Ginger+ Propolis) part / part. The obtained results elucidated that all of the tested materials were effective against AFB disease. Under the laboratory conditions Tylosin $^{\circledR}$ gave higher efficient effect expressed by inhibition zone with $2.77 \mathrm{~cm}$ diameter, versus Propolis which was the lowest efficient material $(0.13 \mathrm{~cm}$ diameter $)$. The other tested materials of Cinnamon oil, Aloe vera, Terramycin ${ }^{\circledR}$, Sulfa dimidin sodium ${ }^{\circledR} \mathbf{2 0 \%}$, and Ginger gave varied efficiency represented by more or less inhibition zone diameters of $2.067,1.933,1.83,0.77$ and $0.16 \mathrm{~cm}$ respectively. In the treated apiaries Tylosin ${ }^{\circledR}$ gave higher reduction - 94.1\%, while Ginger gave the lowest efficacy with $\mathbf{4 0 . 6 \%}$ reduction.
\end{abstract}

Keywords: Natural Extracts, Antibiotics, American foulbrood.

\section{INTRODUCTION}

Disease is a major problem for virtually all organisms. It is an especially severe problem for social insects because their nests provide profitable microhabitats where parasites and pathogens find favorable temperatures and humidity's along with high concentrations of hosts (Schmid-Hempel, 1998).American foulbrood (AFB) is the fatal one of the most devastating and widespread disease of honey bee (Apis mellifera L.). It is caused by the bacterium Paenibacillus larvae larvae ( $P$. l. larvae) (formerly: Bacillus larvae) microaerophilic, Gram positive, spore forming bacterium Paenibacillus larvae. The causative organism can produce over one billion spores in each infected larva. Spores of $P$. larvae can survive in bee products (honey, wax and dry larval scales) and in the environment for 3 to 10 years. The purified spores can survive even more than 70 years (Rudenko, 1987). Also

${ }^{1}$ Plant Protection Dep, Faculty of Agriculture Saba Basha, Alexandria University, P.O. Box 21531, Bolkley, Alexandria , Egypt

${ }^{2}$ Dep.of apiculture Res.,center, Alex, Egypt.

Received June 13, 2017, Accepted July 16, 2017
(Owayss, 2007) mentioned that this infectious disease is one of the most destructive diseases of the honey bee; causes a great economic loss in beekeeping industry worldwide.

The infection can be transmitted to a larva from nurse bees or by spores remaining at the base of a brood cell. Although the larval stages of bee workers, drones and queen are susceptible to infection; under natural conditions infected queen and drone larvae are rarely seen (TAS, 2007).

\section{MATERIALS AND METHODS}

\section{Diagnosis of American Foulbrood disease}

Field examination of selected apiaries for inspection of the disease was based on the detected morphological features and biological aspects of infected cells and larvae of honey bee. To detect AFB disease, the investigation procedures were followed the adopted steps of investigation, according to (Miyagi et al. 2000).The evaluated plant materials and antibiotics were performed as laboratory microbiological tests and field application in the treated apiaries.

The performed control techniques were run along May 2016, upon inspected honey bee colonies of Carniolan hybrid.

The results were recorded along an experimental period of 8 days, at two days intervals. The effectiveness of tested material on the growth of the causative pathogen by using inhibition zone technic, which are measured in diameter by $\mathrm{cm}$.

2. Application of different materials for the management of the AFB disease.

\subsection{Laboratory studies.}

Experiments were conducted at the laboratory of Plant Pathology, Department Faculty of Agriculture. (Saba - Basha)

\section{2. The isolate of Paenibacillus larvae larvae.}

The isolate of $P$. l. larvae. obtained from Arid lands cultivation Research Institute - SARTA City, Borg ElArab, Alex. 
Table 1. Survey of honey bee disease (AFB) at inspected apiaries, in eight districts in El-Beheira and Kafr ElSheikh Governorates

\begin{tabular}{llccl}
\hline Governorate & DISTRICTS & $\begin{array}{c}\text { No. of } \\
\text { Inspected } \\
\text { colonies }\end{array}$ & $\begin{array}{c}\text { No. of } \\
\text { Infected } \\
\text { colonies }\end{array}$ & Materials \\
\hline El-Beheira & Nedeba & 153 & 16 & Tylosin $^{\circledR}$ \\
& Zawyet Ghazal & 73 & 2 & Cinnamon oil \\
& Abees5 & 188 & 6 & Aprogin trial (Aloe vera, propolis and Ginger) \\
& Hosh Isa & 97 & 7 & Aloe vera \\
& Kom Hamada & 98 & 4 & Terramycin \\
& El-Nobaria & 57 & 3 & Sulfa dimidin sodium ${ }^{\circledR} 20 \%$ \\
Kafr El-Sheikh & Fowa & 124 & 4 & Propolis \\
& Hammol & 54 & 4 & Ginger \\
\hline
\end{tabular}

\subsection{Preparation of tested natural extracts.}

\subsubsection{Ginger}

Ten grams $(10 \mathrm{~g})$ of peeled rhizome of ginger were mixed with $25 \mathrm{ml}$ of distilled water in a blender to obtain a concentration of $40 \%$ of a fresh juicy solution (Gin.S). The obtained solution was admixed with the prepared feeding solution at a rate of $10 \mathrm{ml} \mathrm{Gin.S}+500$ $\mathrm{ml}$ of $50 \%$ sugar syrup which had been offered to the colony. Amin and Hamza (2006).

\subsubsection{Cinnamon}

Cinnamon oil (Cin.O) was extracted by steam distillation by replacing $100 \mathrm{~g}$ of dried grand cinnamon bark in the extraction flask. To prevent oxidation process and dry deposition of oil, sodium sulfate $\left(\mathrm{Na}_{2} \mathrm{SO}_{4}\right)$ was immediately used for desiccation after distillation. The extracted oil samples were kept in sealed dark glass bottles at $4{ }^{\circ} \mathrm{C}$ until they are being used. The feeding solution offered to the honey bee colony contained $1 \mathrm{ml}$ of Cin.O $+500 \mathrm{ml}$ of $50 \%$ sugar syrup. Gupta et al. (2008).

\section{3.3. Propolis}

One kilogram $(1 \mathrm{~kg})$ of the old sliced black combs was put inside a piece of muslin and hanged inside one liter (11) of distilled water. The water was then boiled for $5 \mathrm{~min}$. The obtained solution after boiling was considered to be a propolis carrying material and was stored until it has been used. Ten milliliters of that prepared solution were sprayed on infected cells in the combs of each examined colony. Popova et al.(2005).

\section{3.4. Aloe vera}

To evaluate the efficiency of Aloe vera against the disease of AFB, two different technical methods were adopted. The first one was run by cutting the leaves of the plant to small pieces and replacing them on the bottom of plastic container punctured with numerous holes on which these pieces were settled. The flow of the released juice from the replaced plant cuttings was received and collected in a plastic container fixed under the first one. The $2^{\text {nd }}$ one was performed by cutting the leaves into rectangular pieces $(5 \times 20 \mathrm{~cm})$. Each piece was dusted with $30 \mathrm{~g}$ of sugar powder, then was introduced to the colony. Eshun and $\mathrm{He}$ (2004).

\section{The used antibiotics against AFB}

\subsection{Terramycin-25x ${ }^{\circledR}$}

Terramycin (oxytetracycline hydrochloride) is a broad-spectrum antibiotic used to treat a wide variety of bacterial infections. The brand name drug Terramycin is no longer available in the USA. The antibiotic was added to the infected colony by following techniques, whereas one gram of Terramycin was diluted in 3 liters of sugar syrup and offered at a rate of $1 / 2$ liter/colony or admixed with 5 grams of sugar powder or $125 \mathrm{~g}$ candy. Terramycin added to sugar powder was changed every 12 days, while that added to the sugar syrup and the candy was changed every 4 days and every 11 weeks respectively. These treatments were stopped 3 weeks before the appearance of the nectar. Kochansky et al. (2001).

\section{2. Tylosin $^{\circledR}$}

Tylosin is an antibiotic as well as a bacteriostat feed additive used in veterinary medicine. It has a broad spectrum of activity against Gram-positive organisms and a limited range of Gram-negative organisms. It is found naturally as a fermentation product of Streptomyces fradiae. It is a macrolide antibiotic. Hirsch et al. (1999).

\section{3. Sulfa dimidine Sodium ${ }^{\circledR} 20 \%$}

Sulfa dimidine or sulfa methazine is a sulfonamide antibacterial. Other names include sulfa dimerazine, sulfa dimezine, and sulfa dimethyl pyrimidine. Bacteriostatic activity of sulfa dimidine is based on competitive inhibition of p-aminobenzoic acid incorporation in the molecule of folic acid which participates in protein synthesis in the protoplast of causative organisms. 


\section{Media preparation}

The media used for the growth of the isolates were Obtained from Dr. Said Behery, Plant Pathology Lecturer at Faculty of Agriculture Saba Basha, Alex. University, PhD., Bacteriology

This method is based on the detection of pathogenic bacteria in bee hive which shall be done by bacterial cultivation and isolation steps in order to obtain pure culture. The media used are Tryptic soy broth. The bacteria identification is further confirmed by a set of biochemical tests to confirm the presence of $P$. l. larvae.

Tryptic soy broth(TSB) consists of $15 \mathrm{~g}$ tryptone, $5 \mathrm{~g}$ soytone, $5 \mathrm{~g}$ sodium chloride per liter of medium( $\mathrm{PH}$ $7.3 \pm 0.2$ ).MYPGP broth consists of $10 \mathrm{~g}$ mueller 23 hinton broth, $15 \mathrm{~g}$ yeast extract, $3 \mathrm{~g} \mathrm{~K}_{2} \mathrm{HPO}_{4}, 2 \mathrm{~g}$ glucose, and $1 \mathrm{~g}$ sodium pyruvate per liter of medium (ph7.3 \pm 0.2 ), the media was autoclaved at $121^{\circ} \mathrm{Cfor}$ a minimum sterilization time of 30 minutes. Glucose was filtered sterilized and added to media prior to use. For solid media (TSB or MYPGP agar)we used $20 \mathrm{~g}$ of agar per liter of medium.(Piccini et al. 2002).

\section{RESULTS AND DISCUSSION}

The effectiveness of tested material on the growth of the causative pathogen by using inhibition zone technic:

The results included in Table (2), elucidate that in comparison to the untested control all of the tested materials were effective more or less extent inhibited the growth of the causative pathogen of the American foulbrood (AFB).The results were recorded along an experimental period of 8 days, at two days intervals. For each of tested: Tylosin ${ }^{\circledR}$, Terramycin ${ }^{\circledR}$, Sulfa dimidin sodium $^{\circledR} 20 \%$, Cinnamon oil and Aloe vera the inhibition zone appeared after 2 days. While, Propolis and Ginger didn't indicate any effect against the pathogen without revealence of inhibition zone. Whereas after 2 days Tylosin $^{\circledR}$ recorded the highest inhibition zone diameter with average of $1.9 \mathrm{~cm}$, Aloe vera $(0.8 \mathrm{~cm})$, Cinnamon oil $(0.6 \mathrm{~cm})$ Teramycin ${ }^{\circledR}(0.5$ $\mathrm{cm})$ and Sulfa dimidin sodium $^{\circledR} 20 \%(0.21 \mathrm{~cm})$.
Furtherly after the fourth day Propolis still not effective against the pathogen; Tylosin ${ }^{\circledR}$ was the more efficient with inhibition zone diameter of $(2.4 \mathrm{~cm})$ followed by Cinnamon oil , Aloe vera, Terramycin ${ }^{\circledR}$, Sulfa dimidin sodium ${ }^{\circledR} 20 \%$ and Ginger, which recorded inhibition zones averaged $1.80,1.47,1.01$, and $0.08 \mathrm{~cm}$, respectively.

After the $6^{\text {th }}$ day, the inhibition zones appeared in all performed treatments. In this concern, Tylosin ${ }^{\circledR}$ recorded the same larger diameter of $2.4 \mathrm{~cm}$, followed by the descendingly estimated diameters for Cinnamon oil, Aloe vera, Terramycin ${ }^{\circledR}$, Sulfa dimidin sodium ${ }^{\circledR}$ $20 \%$, Ginger and propolis, with means of $2.00,1.73$, $1.21,0.53,0.11$ and $0.09 \mathrm{~cm}$, in respect

At the end of experiment, after 8 days, Tylosin ${ }^{\circledR}$ $(2.767 \mathrm{~cm})$ was still the utmost efficient material, versus the lowest effective propolis $(0.13 \mathrm{~cm})$, while the other evaluated materials, Cinnamon oil, Aloe vera, Terramycin $^{\circledR}$, Sulfa dimidin sodium ${ }^{\circledR} 20 \%$ and Ginger were more or less efficient indicating inhibition zones averaged $2.067,1.933,1.83,0.77$ and $0.16 \mathrm{~cm}$ respectively.

Statistical analysis of data showed highly significant differences between the performed treatments, which proved the significant efficiency of these tested materials, in particular the $\operatorname{Tylosin}^{\circledR}$ which gave increased efficiency, represented by the highest level of inhibition zone compared to the other tested materials against the pathogen.

The same evaluated natural materials and antibiotics, in addition to the adopted mixture of Aprogin (Aloe vera, propolis and Ginger) 1:1 part / part were evaluated under apiary Conditions, to determine their potency against the disease AFB of bee colonies.

The results included in Table (3), elucidate the inspected efficiency of eight tested materials against AFB disease in infected colony. In general, all the tested materials more or less extent were effective against AFB disease.

Table 2. Inhibition zone levels during 8 days with interval 2 days

\begin{tabular}{lcccc}
\hline \multirow{2}{*}{ Materials } & \multicolumn{4}{c}{ Average diameter (cm) of inhibition zone } \\
\cline { 2 - 5 } & 2 days & 4 days & 6 days & $\mathbf{8}$ days \\
\hline Tylosin $^{\circledR}$ & 1.9 & 2.4 & 2.4 & $2.767^{\mathrm{a}}$ \\
Terramycin $^{\circledR}$ & 0.5 & 1.01 & 1.21 & $1.833^{\mathrm{c}}$ \\
Sulfa dimidin sodium $^{\circledR} 20 \%$ & 0.21 & 0.39 & 0.53 & $0.767^{\mathrm{d}}$ \\
Cinnamon oil & 0.6 & 1.80 & 2.00 & $2.067^{\mathrm{b}}$ \\
Aloe vera & 0.8 & 1.47 & 1.73 & $1.933^{\mathrm{c}}$ \\
Propolis & 0.0 & 0.0 & 0.09 & $0.133^{\mathrm{e}}$ \\
Ginger & 0.0 & 0.08 & 0.11 & $0.167^{\mathrm{e}}$ \\
Control & 0.0 & 0.0 & 0.0 & $0.00^{\mathrm{f}}$ \\
\hline
\end{tabular}

L.S.D $=0.203$ 
Table 3. Effect of evaluated materials on the rate infected cells with AFB in the treated honey bee comb

\begin{tabular}{|c|c|c|c|c|c|c|}
\hline \multirow{3}{*}{ Materials } & \multirow{3}{*}{ DISTRICTS } & \multicolumn{4}{|c|}{ Mean number of infected cells } & \multirow{3}{*}{$\begin{array}{c}\text { General } \\
\text { mean } \\
\text { Reduction } \\
(\%)\end{array}$} \\
\hline & & \multicolumn{2}{|c|}{$\begin{array}{c}\text { Mean number } \\
\text { before application }\end{array}$} & \multicolumn{2}{|c|}{$\begin{array}{c}\text { Mean number after } \\
\text { application }\end{array}$} & \\
\hline & & $\begin{array}{l}\text { Treated } \\
\text { colony }\end{array}$ & $\begin{array}{l}\text { Untreate } \\
\text { d colony }\end{array}$ & $\begin{array}{l}\text { Treated } \\
\text { colony }\end{array}$ & $\begin{array}{c}\text { Untreated } \\
\text { colony }\end{array}$ & \\
\hline Tylosin $^{\circledR}$ & Nedeba & 23.667 & 18.333 & 1.667 & 22.000 & 94.1 \\
\hline Cinnamon oil & Zawyet Ghazal & 21.000 & 20.333 & 3.000 & 20.000 & 85.9 \\
\hline *Aprogin trial & Abees5 & 22.000 & 18.333 & 3.333 & 18.667 & 85.12 \\
\hline Aloe vera & Hosh Isa & 19.000 & 19.667 & 5.667 & 20.333 & 71.2 \\
\hline Teramycin $^{\circledR}$ & Kom Hamada & 21.000 & 25.667 & 5.667 & 22.667 & 69.3 \\
\hline Sulfa dimidin sodium ${ }^{\circledR} 20 \%$ & El-Nobaria & 24.667 & 25.667 & 8.000 & 22.667 & 63.3 \\
\hline Propolis & Fowa & 15.667 & 18.333 & 1.333 & 23.333 & 41.3 \\
\hline Ginger & Hammol & 19.667 & 25.667 & 10.333 & 22.667 & 40.6 \\
\hline
\end{tabular}

*(Aprogin): Emptied each of the tested materials of Aloe vera, propolis and Ginger

9. Redution $=\frac{\text { number in the transaction after application } \times \text { Number in control before application }}{\text { num_er in the transaction before application } \times \text { Number in control after application }}$

In the treated apiaries at Nedeba district, Tylosin ${ }^{\circledR}$ gave higher reduction - $94.1 \%$, while ginger gave the lowest efficacy with $40.6 \%$ reduction at Hammol. In case of the other tested materials, the general mean reduction of infected cells to $85.9,85.12,71.2,69.3,63.3$ and 41.3 at the different treated and inspected apiaries in these districts ( Table 3).

These above cited results are in harmony with those mentioned in the works of Kochansky et al (2001).who showed that the five selected antibiotics Oxytetracycline, monesin, Tylosin ${ }^{\circledR}$, Erythromycin and Lincomycin were equally active against resistant and susceptible American foulbrood AFB. Also, Gende et al. (2009) proved the potential effect of Cinnamon oil in controlling AFB disease.

\section{REFERENCES}

Amin, A. and A. Hamza 2006. Effects of Roselle and Ginger on cisplatin induced reproductive toxicity in rats. Asian J. Androl., (5): 607-612.

Eshun. K. and Q. He. 2004. "Aloe vera: a valuable ingredient for the food, pharmaceutical and cosmetic industries--a review". Crit Rev Food Sci Nutr. 44 (2): 91-6

Gende, L .B ., M . D. Maggi, N. Damiani, R . Fritz, M . J. Eguaras and I . Floris 2009. Advances in the apiary control of the honeybee American Foulbrood with Cinnamon (Cinnamomum zeylanicum) essential oil. Bull. Insectol., 62 (1): 93-97.

Gupta, C., A. P. Garg, R. C. Uniyal and A. Kumariz 2008. Comparative analysis of the antimicrobial activity of cinnamon oil and cinnamon extract on some food-borne microbes. African J. Microbiol. Res.2(9): 247-251.

Hirsch, R., T. Ternes, K . Haberer and KL .Kratz 1999. Occurrence of antibiotics in the aquatic environment. The Science of the total environment, 225:109-118.
Kochansky, J., D. A. Knox, M. Feldlaufer and J. S. Pettis 2001. Screening alternative antibiotics against oxytetracycline-susceptible and resistant Paenibacillus larvae, Apidologie., 32: 215-222.

Miyagi, T., C. Y. S. Peng, R. Y. Chuang, E. C. Mussen, M. S. Spivak and R. H. Doi 2000. Verification of oxytetracycline-resistant American foulbrood pathogen Paenibacillus larvae in the United States. J. Invertebr. Pathoil., 75:95-96.

Owayss, A. O. 2007. Preliminary investigation on American foulbrood disease recording the infection in the apiaries at Fayoum Governorate. Ann . Agric., Sci. Moshtohor, 45(2): $903-910$

Piccini, C., B. D'alessandro, K. Antunez and P. Zunino 2002. Detection of Paenibacillus larvae subspecies larvae spores in naturally infected bee larvae and artificially contaminated honey by PCR. World J. Microbiol. and Biotechnol, 18(8): 761- 765.

Popova, M., S. Silici, O. Kaftanoglu and V. Bankova 2005. Antibacterial activity of Turkish propolis and its qualitative and quantitative chemical composition. Phytomedicine, 12: 221-228.

Rudenko, E. V. 1987. Manuscript. Dissertation for Doctorate of Veterinary Science; American foulbrood of honey bees and its vaccine prophylaxis (in Russia), Minsk, Belarus.

Schmid-Hempel, P. 1998. Parasites in Social Insects. Princeton Univ. Press, Princeton, NJ 26 (3):.255-271.

TAS. 2007. (Thai Agricultural Standard). The standard title has been revised from "Thai Agricultural Commodity. and Food Standard (TACFS)" to in accordance with the enforcement of The Agricultural Standards Act B.E. 2551 2007. Published in the Royal Gazette Vol.125 Special Section 3 D. 


\section{الملخص العربي}

تأثير بعض المستخلصات النباتية وبعض المضادات الحيوية على مكافحة مرض تعفن الحضنة الأمريكي

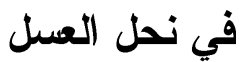

حسن علي مصباح، نجدة أحمد السيد، محمد السيد مرسي، ماجدة بهجت القاضي، سعيد بجيري، جمال عبد الناصر الحمامي أجريت هذه الدراسة لنقييم بعض المستخلصات النباتبــة في التطبيق الحقلي أعطى التيلوزين أعلى تأثير بمعـدل

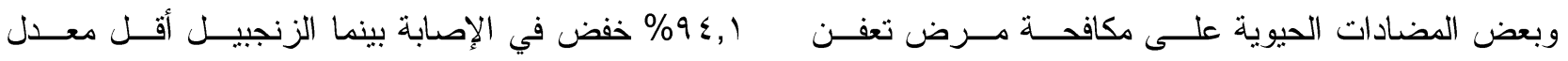

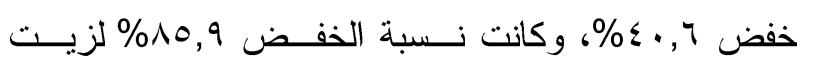

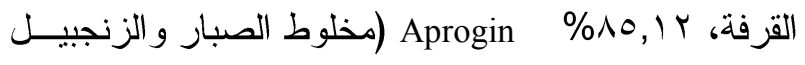

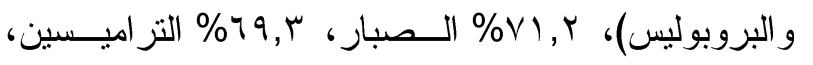

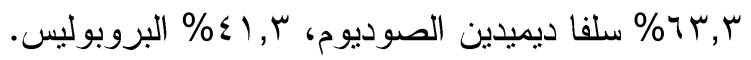

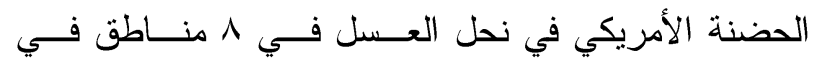

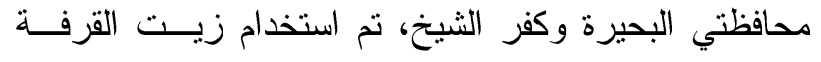

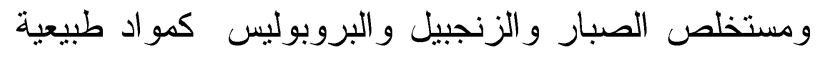

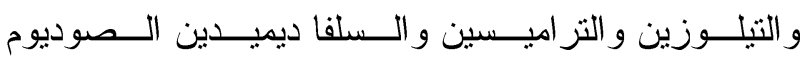
كمضادات حيوية.

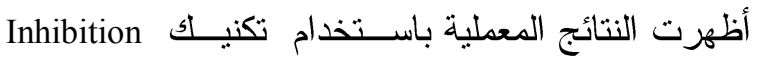

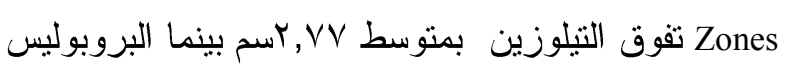
حقق أقل تأثير بمنوسط ع (, ••سم. 